\title{
Early and double breeding in a pack of hybrid wolves in Cal- abria (Southern Italy)
}

\author{
Francesca Crispino", Martina Costanzo', Angelo Lucia' \& Giacomo Gervasio' \\ Greenwood s.c., Via Pozzillo 21, 87045 Dipignano (Cosenza), Italy \\ *Corresponding author, e-mail: crispinofrancesca1@gmail.com
}

\begin{abstract}
Some anomalies in the breeding cycle of a pack of wolf-dog hybrids in a semi-anthropized area in the central-western part of Calabria are described. The data were collected between October 2019 and March 2021 by direct observations and video-camera trapping. In addition to recording anomalous morphological and phenotypic traits present in varying degrees in some individuals of the pack, we documented for two consecutive years the breeding of a subordinate female that was about three months early compared with the normal wolf breeding cycle. Moreover, in spring 2020, it was possible to observe double breeding within the same pack, due to the regular reproduction of the dominant female.
\end{abstract}

KEY WORDS Canis lupus; Wolf $\times$ dog hybridization; introgression; reproductive physiology; early breeding.

Received 26.03.2021; accepted 13.05.2021; published online 28.05.2021

\section{INTRODUCTION}

Wolf $\times$ dog hybridization has been documented in several parts of the world at different times (Salvatori et al., 2020; Kusak et al., 2018; Pilot et al., 2018; Hindrikson et al., 2012; Godinho et al., 2011; Randi, 2011; Vilà et al., 2003). In the past, episodes of crossbreeding with dogs were presumably less frequent and thus genetically more easily diluted in wolf populations. However, there has been an increase of cases in recent years, especially in countries where the large number of stray dogs and other anthropogenic factors have favored opportunities for contact (in Ciucci, 2012).

In Italy, recent estimates of the timing of hybridization events indicate that the peak of recorded cases occurred at the end of the 1990s (Galaverni et al., 2017), suggesting that most of the hybrids date to the phase of the wolf's numerical and range expansion that started in those years and is still ongoing (Fabbri et al., 2007; Galaverni et al., 2015; Marzano et al., 2017; Marucco et al., 2018).

Hybridization with dogs and the deleterious consequences of gene introgression currently represent one of the main threats for conservation of the wolf (Donfrancesco et al., 2019; Hindrikson et al., 2017). The phenomenon places at risk not only its genomic integrity but also its adaptive capacity, with the irreversible loss of allele frequencies likely responsible for ecological and behavioral adaptations (Lynch \& O’Hely, 2001).

Despite the increasing number of genetic studies to evaluate the amount of introgression in natural populations, little is known about the behavior and ecology of hybrids in the wild (Lescureux \& Linnell, 2014). Recent studies, also carried out via satellite telemetry, have analyzed the spatial and alimentary ecology in some packs of wolf-dog hybrids (Molinari, 2020). However, aspects related to physiology and reproductive behavior remain poorly documented and mostly refer to studies con- 
ducted in the last century. In particular, some differences in reproductive physiology were recorded in an 8-year experimental work conducted on 101 individuals of wolf hybrids in captivity (Iljin, 1941). That study revealed sexual receptivity of the hybrids only once a year as in wolves, but also found in most of the individuals an advance of 2-3 months compared to the wolf's normal breeding period.

Although the extent of hybridization is poorly known also in Calabria, cases have recently been recorded both in areas of stable presence of the species, e.g. in the protected areas of Pollino and Aspromonte (AA.VV., 2019), and in semi-anthropized rural areas of more recent colonization, as the authors report below.

\section{MATERIAL AND METHODS}

In the present note, investigations carried out over a period of about a year and a half on a pack of wolf-dog hybrids in the wild are described, and some data on the ecology and reproductive physiology are provided. In particular, cases of reproduc- tion by two different females are documented, one of which was about 2-3 months early compared to the normal wolf breeding period.

The investigations began in autumn 2019 when, during some surveys aimed at expanding the study of the species in Calabria, the presence of a group composed of three individuals was detected, two of which with anomalous traits compared to the wolf's wild phenotypic standard. The pack's core area, with a high degree of anthropization and environmental degradation, was identified in the centralwestern part of Calabria in a foothill band overlooking the coast of the Tyrrhenian Sea, characterized by various types of productive activities (agricultural, industrial and artisanal) as well as the presence of various strategic infrastructures.

The data were acquired by means of direct observations and video-photographic surveys (two surveys per month for a total of 36 days), programmed opportunistically and making use of a digital reflex camera with telephoto lens and a camera trap with low glow infrared LEDs set for video recording (two camera-traps for 75 days in two different recording sessions).

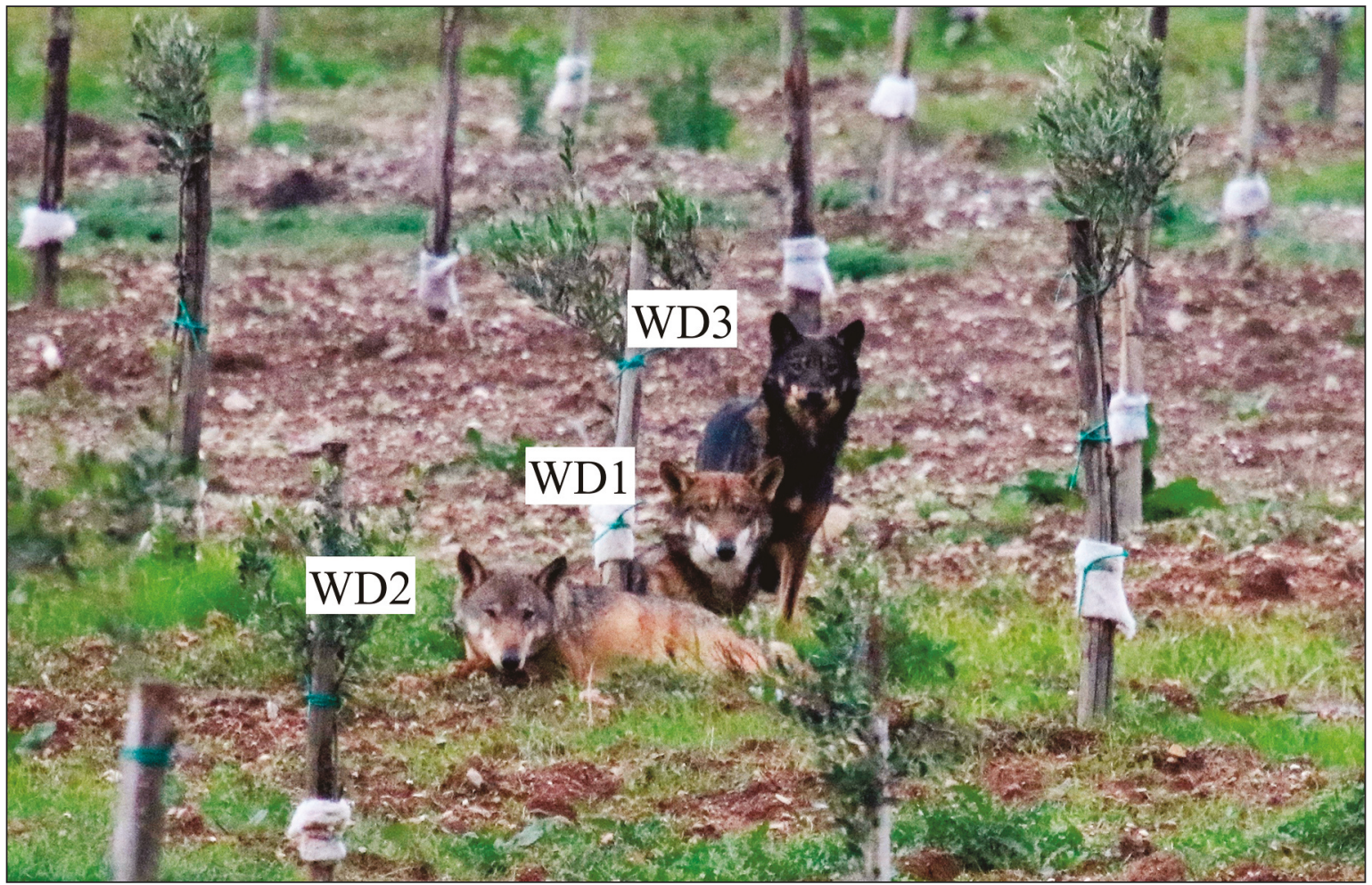

Figure 1. Dominant couple (WD1 and WD2) and subordinate female (WD3). 


\section{RESULTS}

It was possible to distinguish a phenotypically wild-type female (WD2) and two other individuals, a female (WD3) and a male (WD1), with signs of hybridization (Figs. 1, 2). The anomalous characters of each individual (Table 1) refer to the phenotypic markers of hybridization reported in the literature (Ciucci et al., 2003; Anderson, 2009; Ciucci, 2012; Caniglia et al., 2013; Galaverni et al., 2017). From behavioral observations, it was possible to define the hierarchy of the pack by identifying the dominant couple as WD1 and WD2. At the end of February 2020, WD3 was observed in the lactation phase, and during subsequent monitoring the yelps of an unknown number of pups coming from the den site were heard. These observations document the anomalous breeding of a subordinate female of the pack that was ca. 2-3 months early compared to the wolf standard. Further checks revealed the presence of only one pup (WD4) with clear signs of hybridization (Fig. 2) whose phenotypic traits suggest that WD3 bred with an individual external to the pack, probably one of the local shepherd's dogs phenotypically very similar to WD4. The appearance of traits related to the different breeds of dogs involved in crosses is a naturally expected consequence and is also described in some studies conducted in captivity (Silver \& Silver 1969).

In the following months, direct observations documented the continuous use of the area and the constant association of the three adults and the pup. In June 2020, WD2 was observed with clearly visible mammae; thus, it was possible to confirm the reproduction of the dominant couple consistent with the normal breeding seasonality of wolves.

Following the installation of two camera traps near the breeding site, some of the dynamics governing the pack's social organization were observed. In this phase, the role of helper assumed by WD4 became clear; in the absence of the adults, it often remained to support and watch over the newborn pups. At the end of June, it was possible to document the presence of four other pups which in the subsequent growth stages presented anomalous phenotypic traits (Table 1; Fig. 2). The pack composed in this way remained together until the sub-

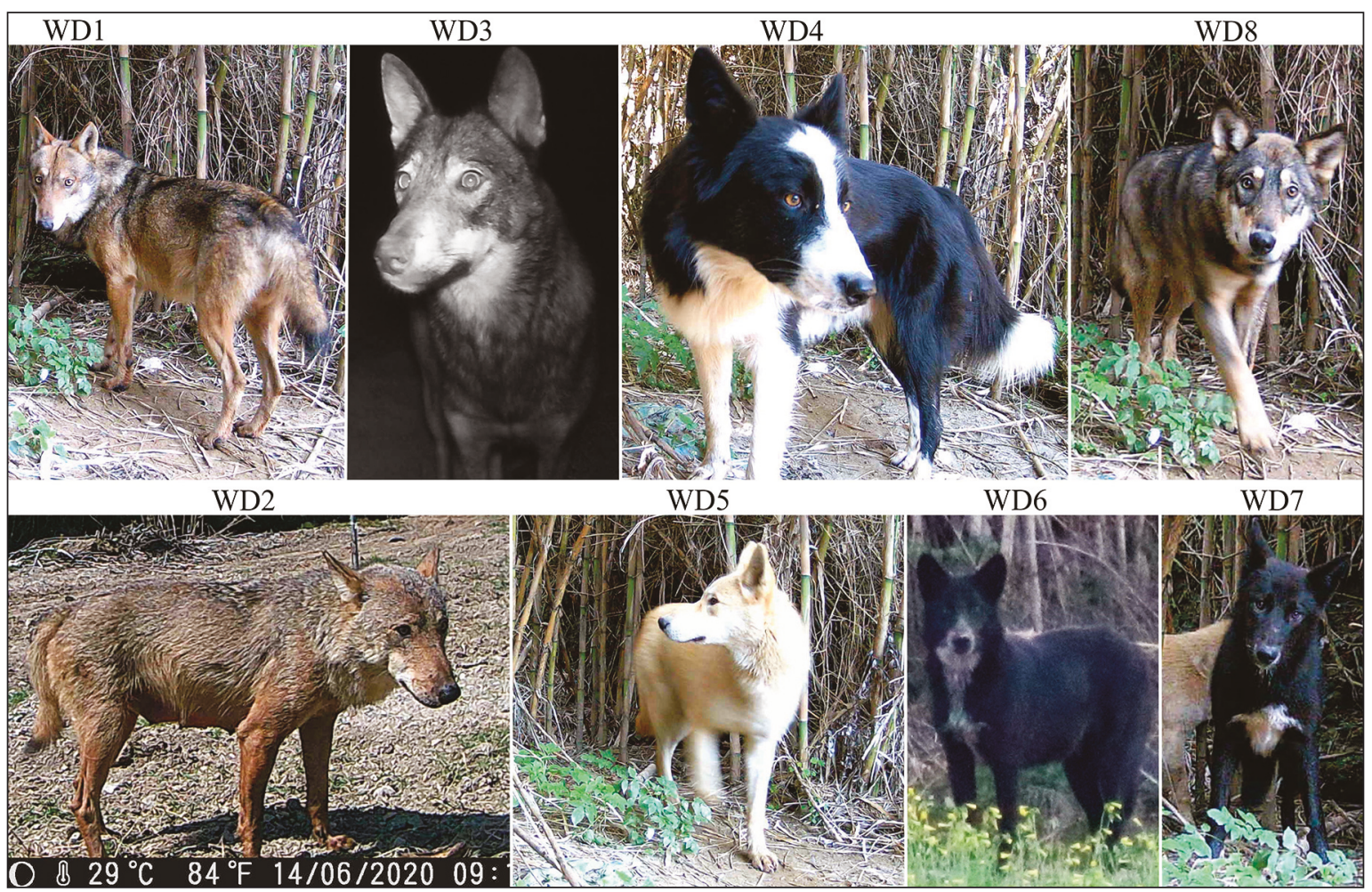

Figure 2 - Pack's individuals observed until March 2021. 


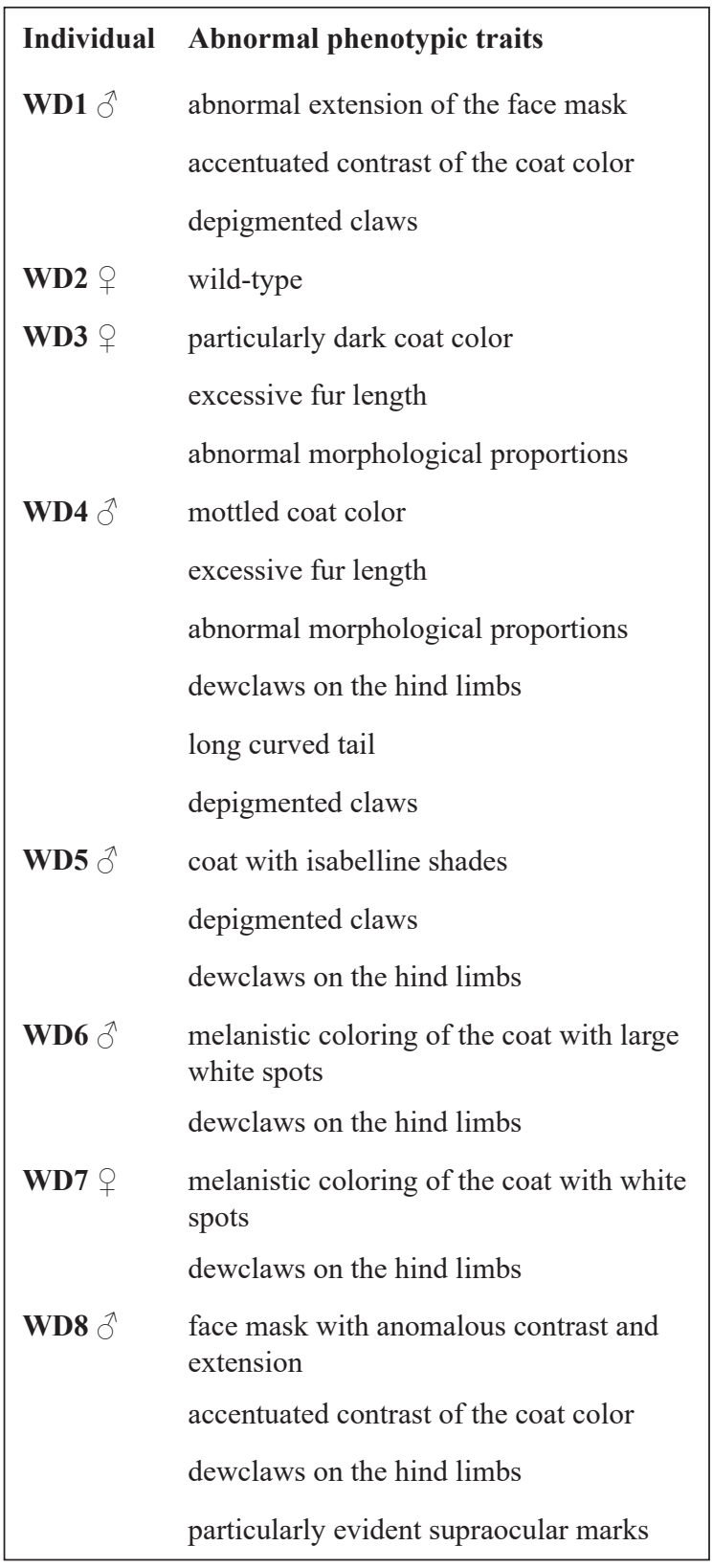

Table 1. Abnormal phenotypic traits recorded for each individual of the pack.

sequent 2021 reproductive phase, and at the end of February of the same year the early breeding of WD3 was observed again. Although there is a lack of genetic data able to define the generation in which the hybridization occurred and phenotypic traits are less reliable from a methodological perspective, in this specific case all the character states currently recognized as an effective indication of hybridization were recorded (melanism, dewclaws on the hind legs, depigmented claws). Moreover, the observed reproductive dynamics and the simultaneous presence of multiple diagnostic traits objectively indicate genetic introgression in the pup (WD4) and, more generally, the hybrid origin of the pack. The atypical social structure compared to traditional wolf packs probably caused the low reproductive success of WD3. In fact, lack of parental care and lower pack cohesion can lead to a higher rate of mortality of pups of hybrids with respect to wolves (Mengel 1971; Vilà \& Wayne 1999; Godinho et al., 2011).

Although it was not possible to determine the actual size of the pack's territory, the constant frequentation of the home site throughout the year suggests that it is extremely small and stable. The absence of potential natural prey suggests the presence of food sources of anthropogenic origin available all year round. This is supported by the known tendency in the area for illegal disposal of both butchery wastes and carcasses of dead farm animals. In some areas with strong anthropization and scarcity of wild prey, wolves have exploited resources of anthropogenic origin in an opportunistic manner (Boitani 1982; Meriggi et al. 1991; Ciucci \& Boitani 1998). It is likely that the absence of conflicts with the interests of the local inhabitants (and of eventual poaching incidents) is, at least in part, due to this type of food availability. Certain factors such as the availability of water and the strategic position with possible escape routes may have determined the choice of the home site, despite the absence of vegetation cover of the main daily resting site. In fact, the ecological observations described herein were possible thanks to an ideal situation of observability, in a logistical context that guaranteed to the monitored individuals the perception of safety and control of the surrounding area.

\section{CONCLUSIONS}

The present work is one of the few field studies on the reproductive ecology of wolf $\times$ dog hybrids in a semi-anthropized context. The reported observations are further testimony to the possible behavioral and physiological changes caused by anthropogenic hybridization in the wolf. In the absence of a clear and shared way to manage the problem (Salvatori et al., 2020), we believe that any 
contribution is useful to highlight one of the most insidious problems (with irreversible consequences) for conservation of the wolf.

\section{REFERENCES}

AA.VV., 2019. Convivere con il lupo per preservare. Il sistema dei Parchi nazionali dell'appennino meridionale per lo sviluppo di misure coordinate di protezione per il lupo. Report 2018-2019.

Anderson T.M., VonHoldt B.M., Candille S.I., Musiani M., Greco C., Stahler D.R., Smith D.W., Padhukasahasram B., Randi E., Leonard J.A., Bustamante C.D., Ostrander E.A., Tang H., Wayne R.K. \& Barsh G.S., 2009. Molecular and evolutionary history of melanism in North American gray wolves. Science, 323: $1249-1390$.

https://doi.org/10.1126/science. 1165448

Boitani L., 1982 Wolf management in intensively used areas of Italy F.H. Harrington \& P.C. Paquet (Eds.), Wolves of the World, Noyes Publishing Co., Park Ridge (1982), pp. 158-172.

Caniglia R., Fabbri E., Greco C., Galaverni M., Manghi L., Boitani L., Sforzi A. \& Randi E. 2013. Black coats in an admixed wolf - dog pack is melanism an indicator of hybridization in wolves?. European Journal of Wildlife Research, 59: 543-555.

https://doi.org/10.1007/s10344-013-0703-1

Ciucci P., Boitani L.1998. Il lupo. Elementi di biologia, gestione, ricerca. Istituto Nazionale della fauna selvatica "Alessandro Chigi”, Documenti Tecnici, 23.

Ciucci P., Lucchini V., Boitani L. \& Randi E. 2003. Dewclaws in wolves as evidence of admixed ancestry with dogs. Canadian Journal of Zoology, 81: 20772081. https://doi.org/10.1139/z03-183

Ciucci P., 2012. Ibridazione con il cane come minaccia per la conservazione del lupo: status delle conoscenze e criteri per l'identificazione degli ibridi. LIFE10NAT/IT/265 IBRIWOLF Azione A2 - Messa a punto delle migliori strategie per l'identificazione degli ibridi. Relazione tecnica.

Donfrancesco V., Ciucci P., Salvatori V., Benson D., Andersen L.W., Bassi E., Blanco J.C., Boitani L., Caniglia R., Canu A., Capitani C., Chapron G., Czarnomska S.D., Fabbri E., Galaverni M., Galov A., Gimenez O., Godinho R., Greco C., Hindrikson M., Huber D., Hulva P., Jedrzejewski W., Kusak J., Linnell J.D.C., Llaneza L., López-Bao J.V., Männil P., Marucco F., Mattioli L., Milanesi P., Milleret C., Mysłajek R.W., Ordiz A., Palacios V., Pedersen H.C., Pertoldi C., Pilot M., Randi E., Rodríguez A., Saarma U., Sand H., Scandura M., Stronen A.V., Tsingarska E. \& Mukherjee N., 2019. Unravelling the Scientific Debate on How to Address Wolf-Dog Hybridization in Europe. Frontiers in Ecology and Evolution, 7: 175. https://doi.org/10.3389/fevo.2019.00175.

Fabbri E., Miquel C., Lucchini V., Santini A., Caniglia R., Duchamp C., Weber J.M., Lequette B., Marucco F., Boitani L., Fumagalli L., Taberlet P. \& Randi E. 2007. From the Apennines to the Alps: colonization genetics of the naturally expanding Italian wolf (Canis lupus) population. Molecular Ecology, 16: 1661-1671.

https://doi.org/10.1111/j.1365-294X.2007.03262.x.

Galaverni M., Caniglia R., Fabbri E., Milanesi P. \& Randi E. 2015. One, no one, or one hundred thousand: how many wolves are there currently in Italy?. Mammal Research, 61. https://doi.org/10.1007/s13364-015-0247-8.

Galaverni M., Caniglia R., Pagani L., Fabbri E., Boattini A., Randi E., 2017. Disentangling Timing of Admixture, Patterns of Introgression, and Phenotypic Indicators in a Hybridizing Wolf Population. Molecular Biology and Evolution, 34: 2324-2339. https://doi.org/10.1093/molbev/msx169.

Godinho R., Llaneza L,. Blanco J.C., Lopes S., Álvares F., Garcìa E.J., Palacios V., Cortès Y., Talegòn J. \& Ferrand N., 2011. Genetic evidence for multiple events of hybridization between wolves and domestic dogs in the Iberian Peninsula. Molecular Ecology, 20: 5154-5166. https://doi.org/10.1111/j.1365-294X.2011.05345.x

Hindrikson M., Männil P., Ozolins J., Krzywinski A. \& Saarma U., 2012. Bucking the Trend in wolf-dog hybridization: first evidence from Europe of hybridization between female dogs and male wolves. PLoS ONE 7:e46465. https://doi.org/10.1371/journal.pone.0046465.

Hindrikson M., Remm J., Pilot M., Godinho R., Stronen A. V., Baltrunait L., Czarnomska S.D., Leonard J.A., Randi E., Nowac C., Akesson M., Bao J.V.L., Alvares F., Llaneza L., Echegaray J., Vilà C., Ozolins J., Rungis D., Aspi J., Paule L., Skrbinšek T. \& Saarma U., 2017. Wolf population genetics in Europe: a systematic review, meta-analysis and suggestions for conservation and management. Biol. Rev. 92, 16011629. https://doi.org/10.1111/brv.12298.

Kusak J., Fabbri E., Galov A., Gomerčić T., Arbanasić H., Caniglia R., Galaverni M., Reljic' S., Huber D., Randi E. 2018. Wolf-dog hybridization in Croatia. Vet. Arh. 88, 375-395. https://doi.org/10.24099/vet.arhiv.170314.

Iljin, N.A. 1941. Wolf-dog genetics. Journal of Genetics 4: 359-414.

Lescureux N. \& Linnell J.D.C., 2014. Warring brothers: The complex interactions between wolves (Canis lupus) and dogs (Canis familiaris) in a conservation context. Biological Conservation, 171: 232-245. http://dx.doi.org/10.1016/j.biocon.2014.01.032 
Lynch M. \& O’Hely M., 2001. Captive breeding and the fitness of natural populations. Conservation Genetics, 2: 363-378. https://doi.org/10.1023/A:1012550620717

Marucco F., Avanzinelli E., Bassano B., Bionda R., Bisi F., Calderola S., Chioso C., Fattori U., Pedrotti L., Righetti D., Rossi E., Tironi E., Truc F., Pilgrim K., Engkjer C. \& Schwartz M., 2018. La popolazione di lupo sulle Alpi Italiane 2014-2018. Relazione tecnica, Progetto LIFE 12 NAT/IT/00080 WOLFALPS - Azione A4 e D1.

Marzano G., Crispino F., Rugge M. \& Gervasio G., 2017. The Wolf (Canis lupus Linnaeus, 1758) recolonization is still ongoing in Southern Italy: a breeding pack documented through camera traps in the Salento Peninsula. Biodiversity Journal, 8: 855-860.

Mengel R.M., 1971. A study of dog-coyote hybrids and implications concerning hybridization in Canis. Journal of Mammalogy, 52: 316-336.

Meriggi A., Rosa P., Brangi A. \& Matteucci C., 1991. Habitat use and diet in the wolf in northern Italy. Acta Theriologica, 36: 141-151.

Molinari L., 2020. PROGETTO LIFE13 NAT/IT/000728 LIFE MIRCO-LUPO "Strategies to minimize the impact of free ranging dogs on wolf conservation in Italy" - Azione D2 Valutazione dell'impatto delle attività di cattura, sterilizzazione e rilascio degli ibridi. Relazione tecnica.

Pilot M., Greco C., VonHoldt B. M., Randi E., Jedrzejewski W., Sidorovich V.E., Konopiński M.K., Ostrander E.A. \& Wayne R.K., 2018. Widespread, long-term admixture between grey wolves and domestic dogs across Eurasia and its implications for the conservation status of hybrids. Evolutionary Applications, 11: 662-680. https://doi.org/10.1111/eva.12595.

Randi E., 2011. Genetics and conservation of wolves Canis lupus in Europe. Mammal Review, 41: 99-111. https://doi.org/10.1111/j.1365-2907.2010.00176.x.

Salvatori V., Godinho R., Braschi C., Boitani L. \& Ciucci P., 2019. High levels of recent wolf $\times$ dog introgressive hybridization in agricultural landscapes of central Italy. European Journal of Wildlife Research, 65. https://doi.org/10.1007/s10344-019-1313-3.

Salvatori V., Donfrancesco V., Trouwborst A., Boitani L., Linnell J. D. C., Alvares F., Akesson M., Balys V., Blanco J. C., Chiriac S., Cirovic D., Groff C., GuinotGhestem M., Huber D., Kojola I., Kusak J., Kutal M., Iliopoulos Y., Ionescu O. \& Ciucci P., 2020. European agreements for nature conservation need to explicitly address wolf-dog hybridisation. Biological Conservation, 248: 1-9. https://doi.org/10.1016/j.biocon.2020.108525

Silver H. \& Silver W.T. 1969. Growth and behavior of the coyote-like canid of Northern New England with observations on canid hybrids. Wildlife Monographs, 17: $1-41$.

Vilà C. \& Wayne R.K. 1999. Wolf-dog hybridization. Conservation Biology, 13: 195-198.

Vilà C., Walker C., Sundqvist A.-K., Flagstad Ø., Andersone Z., Casulli A., Kojola I., Valdman H., Halverson J. \& Hellegren H., 2003. Combined use of maternal, paternal and bi-parental genetic markers for the identification of wolf-dog hybrids. Heredity, 90: 17-24. https://doi.org/10.1038/sj.hdy.6800175. 